\title{
The Dutch Model of Sector-wide Supplementary Pensions: Fund Governance, Finance and European Competition Policy
}

Gordon L Clark, School of Geography, University of Oxford, and Paul Bennett, Department of Geography, University of Edinburgh gordon.clark@geography.ox.ac.uk (draft 3rd March 2000)

\begin{abstract}
There is considerable interest in the design and funding of European pension systems. While many commentators emphasize the financial burden of under-funded European social security systems, less understood are the structure and performance of European supplementary pensions. In this paper, we introduce readers to the Dutch system of funded supplementary pensions focusing upon the governance structure of those pension funds in the context of European competition policy. From the early 1950s, the Dutch government has encouraged the development of employer-sponsored and industry-wide supplementary pensions, covering most employed Dutch workers. As the government has slowly discounted the real value of social security, supplementary pensions have come to play a crucial role in maintaining high levels of income replacement upon retirement. From an AngloAmerican perspective, however, these pension institutions appear quite unusual. In many instances, firms are required to participate in sector schemes denying them the right to make separate arrangements with competing financial institutions. Moreover, many sector schemes are, in effect, mutually-owned financial conglomerates selling services to a captive internal market. Referencing the decision of the European Court of Justice in Maatschappij Drijvende Bokken, this paper assesses the arguments for and against this model of pension provision. While sympathetic to the goals of national social solidarity, the underlying structure of governance unfortunately combines the risks of moral hazard with limited transparency and accountability.
\end{abstract}

Acknowledgements. Research for this paper was supported by AIG Financial Products Corp. (London), the Future Governance programme of the Economic and Social Research Council (UK), and the University of Oxford. We are grateful for the initial support of Robert Hirst and Joe Cassano and the participation of many people interviewed for the project. Chris Verhaegen of the EFRP, Allan Fels, Darryl Biggar and Bernard Phillips of the OECD Competition Committee, Koen de Ryck of Pragma Consulting, and Richard Disney from the University of Nottingham provided expert advice. Karen Bitter, Frank Prinz, and Martin van't Zet from the Vereniging van Bedrijfspensioenfondesen, and Linda Nockler from Greenwich Associates provided access to invaluable data. We have also benefited from the comments of seminar participants at the University of Nottingham and conference participants at the Annual Meeting of the Association of American Geographers (Pittsburgh). None of the above should be held responsible for any omissions or opinions contained herein. 


\section{Introduction}

It has become commonplace to refer to the inexorable ageing of European countries' populations, reflected in increasing dependency ratios (the ratio of those aged 0-14 and over 65 against the working age population) (Gardiner 1999). For instance, the OECD estimates that the average European dependency ratio will rise from 50.4 (year 2000 ) to 67.4 (year 2030). Some countries like Germany (46.7 to 75.1) and The Netherlands (47.7 to 73.2) will be more affected than others like the UK (54.0 to 68.0) and Ireland (49.8 to 54.5) (Leibfritz et al. 1995). In some countries, moreover, adverse demographic trends are also accompanied by significant financial liabilities; dependence upon unfunded or under-funded social security systems will transform the increasing dependency burden into the "demographic bomb". This is the likely fate of France, Germany, and Italy; the significance of demography is closely connected with pension funding (World Bank 1994; but compare Boldrin et al. 1999).

But it would be misleading to suppose that all continental European countries will be similarly affected (Disney 2000). There are significant differences between countries in their reliance upon pillar I (social security) retirement income just as there have been many country-specific initiatives designed to anticipate the "demographic bomb". The Netherlands, for example, would seem to be more like continental Europe with respect to the value and funding of long-term social security obligations. However, over the past decade or so the Dutch government has sought to shift an increasing proportion of individuals' projected retirement income costs to employer-sponsored funded pension plans (pillar II). In this respect, the Dutch retirement income system is characterised by a volume of pension fund assets more akin to the Anglo-American world than continental Europe. Indeed, the OECD (1999, p. 13) estimated that Dutch accumulated pension fund assets were worth 93 percent of GDP compared to UK and US pension fund assets of, respectively, 77.5 percent and 64.4 percent. See also Davis (1995) and Watson Wyatt (1998).

Of the various European retirement income "models", the Dutch system is perceived by policy makers to have a number of advantages over the Anglo-American model (see Davis 1996). In summary terms, it has been suggested by German commentators that the Dutch system preserves elements of co-determination or collective bargaining so essential to post second world war European political stability while providing scope for financial growth and innovation so important in Anglo-American securities' markets. Notwithstanding its modest economic size 
compared to France and Germany, the Dutch economy has been closely connected with the global economy for many years. It is widely perceived to have a corporate governance structure and financial system that usefully combines social solidarity with robust international competitiveness. If the Anglo-American pension system would be difficult for European countries to emulate, the Dutch system may be an effective compromise (see Goodin et al. 1999 on the virtues of the Dutch social democratic welfare). The paper begins with a brief account of the relationship between Dutch social security and pillar II pensions and moves on to the structure and governance of sector-wide pension plans.

Basically, three points are made in this paper. First, the principles of Dutch social solidarity have been the basis of a two-tired national pension system (pillar I and pillar II) that has extensive coverage of eligible workers and equitable consequences in relation to the long-term distribution of retirement income. The European Court of Justice (September 1999) opinion in Maatschappij Drijvende Bokken can be read as a defence of the integrity of such national solutions to the "demographic bomb". 1 This point is made through an analysis of the formal logic underpinning the court decision, set in the context of the structure and organization of sector-wide pension funds and their "captive" financial service firms. ${ }^{2}$ Second, the governance of sector pension funds combined with their intimate connection with collective bargaining raises important issues of selection bias and moral hazard. ${ }^{3}$ While many sector funds may be managed efficiently, the lack of an effective means of disciplining entrenched board members and their managers may discourage the formation of a competitive cost-efficient market for financial services. Third, the idea that national pension systems and financial markets are properly or naturally of limited geographical scope is disputed. We do not doubt the importance of sustaining progressive models of retirement income from those who would discount national goals in favour of a standardized Anglo-American pension model. But we do identify significant potential short-falls in the governance of Dutch sector pension funds.

To sustain our argument, we rely upon material gleaned from interviews with Dutch pension plan representatives, OECD and EU officials, and UK and European pension consultants and lawyers. A summary of the study, those interviewed and the questions asked can be obtained from the first-named author. Our empirical approach is set out in Clark (1998) and substantiated in Bennett (2000a) and Clark (2000) where links are made between the methodology of contemporary economic geography 
and the practice of "close dialogue". Here insider-information on Dutch pensions is combined with a critical assessment of the role and status of Dutch pension institutions. Our intention is to both inform the reader about Dutch pension institutions and set those institutions in wider theoretical and policy contexts. Note, the historical origins and evolution of these institutions are not considered in this paper. Historiography is not our expertise (compare with Swaam 1998). Pensions systems and comparative policy assessment are the threads of knowledge that sustain the arguments of this paper (see Clark 2001 and Stone 1999).

\section{Social Security and Supplementary Pensions}

The literature on comparative social welfare and public policy tends to associate The Netherlands with the institutions of Scandinavian social democracy. For example, in Esping-Anderson's (1989) three-way classification of welfare state regimes The Netherlands was grouped with countries like Denmark and Sweden. His quantitative scoring and qualitative assessments of welfare programmes and policy principles resulted in a three-by-three classification of advanced industrialised states, distinguishing three clusters of states according to three measures of strength (strong, medium and low) (see Table 3.3, p. 74). In Esping-Anderson's analysis The Netherlands was strongly associated with the "socialist" regime in contrast to Austria and Germany (in the conservative cluster) and Australia, Switzerland and the United States (in the liberal cluster). For the most part, the clusters were well-defined and exclusive. The only anomaly appeared to be the United Kingdom scoring low on conservatism, medium on liberal-democratic, and medium on socialism.

Reinforcing this image Ploug and Kvist (1996, p. 84) suggested that the Dutch have "one of the most comprehensive pension schemes in Europe." Relying upon another comparative classification of pensions systems (Salminen 1993), they also associated The Netherlands with Sweden under the schematic model of "citizenship". In both cases, old age public pension systems were designed for universal coverage and the entitlement to a retirement income according to citizenship (or legal residence) and prior earnings. A worker's "Algemeine Onderdomswet" (AOW) entitlement is based, in part, on compulsory contributions in relation to a minimum benefit biased upwards in favour of low-wage workers and against high-wage workers. In combination with private pension entitlements, the allowed maximum retirement income benefit is 70 percent of the final wage. In this sense, the goal of 
social security is equitable income replacement not just "welfare". It was designed to be a form of redistribution applied to the entire population rather than a programme of basic income for the poor (compare with the UK; see Budd and Campbell 1998).

Much more can be written about the subsidiary benefits and effects associated with the Dutch state and European welfare states. For instance, the Dutch social security system and in particular disability and unemployment benefits appear to encourage early retirement when compared to Anglo-American countries like Canada and the United Kingdom (see Gruber and Wise 1997, Table 1 p. 21). Here, however, we should recognise another important aspect of Dutch retirement income policy: the extensive coverage of Dutch workers by employer-sponsored private pension plans. Indeed just as Ploug and Kvist (1996) suggested that European social security systems are, in general, in retreat in terms of benefit levels and coverage rates, Blomsma and Jansweijer (1997) suggested that the Dutch private pension system is increasing important as a supplement to AOW benefits. Not only do private pensions often contain significant early-retirement options, as a matter of public policy supplementary pensions have been required to take-up an increasing share of workers' retirement incomes. In effect, the state has sought to discount the value of its contributions to retirement income thereby discounting its social security burden.

Though not mandatory, 1996 data provided by Prins (1999) suggested that just over 80 percent of Dutch workers were covered by supplementary pension schemes. These schemes can be divided into four types; see the 1997 data published by the Dutch insurance and pension funds regulator (Verzekeringskamer 1999): the privatized public sector pension fund Algemeen Burgerlijk Pensioenfonds (ABP); nearly 850 corporate pension plans; about 82 sector (multi-employer) pension plans; and 11 professional association pension funds. There were also about another 40,000 insured pension schemes used by small enterprises. Much of the subsequent discussion is focused around the sector pension funds, in part because of their share of total Dutch pension fund assets (approx. 66 percent) and their share of covered workers (3.850 million of 5 million total covered workers). Note that the privatized public sector plan remains the largest Dutch plan with about 900,000 participants and assets reputably worth nearly 300 billion Dfl (1999). While there are a handful of large sector plans accounting for the majority of all sector plan participants, most of the 82 sector plans are small in terms of participants and assets. Indeed, based on the only available data (1994) 55 plans had fewer than 10,000 participants (Table 1). 
Plan size is an important issue in pension fund management (Clark 2000). As we shall see in subsequent sections of this paper, plan size also figures prominently in pension fund governance. In many respects, economies of scale determine the costs of service provision inside and outside of pension funds. Further more, the larger the fund or co-operating funds the more sophisticated are financial control systems, member services, and investment management products and services (Greenwich Associates 1999). Just as many sector funds have relatively few members, given the year-to-year full-funding of expected liabilities the size of managed assets is also often small by international standards. In Table 2 we report the distribution of corporate and sector-wide pension funds by asset size (Dfl 1998). This data were provided by the association of sector funds Vereniging van Bedrijfspensioensfondsen (VB) for their 50 participating funds and for the 56 participating funds in the corporate funds association. More than half of the sector funds had assets valued at less than 1 Dfl billion (about $£ 300$ million) while about a third of corporate funds were so valued. A significant proportion of corporate funds were valued at between 1 Dfl billion and 5 Dfl billion in size, and another twenty percent were even larger. Note that the ABP was included on the corporate side of the ledger in Table 2. The largest Dutch sector funds are in the metals industries, manufacturing, and banking and financial services. The largest corporate pension plans include firms with a global reach like Royal Dutch Shell, KLM, and Philips.

Dutch pension funds are almost all fully-funded defined benefit (DB) plans. There are exceptions including the ABP which, prior to privatisation in 1996, was significantly under-funded. Unlike the Anglo-American world, Dutch pension funds are directly monitored year-to-year by the insurance regulator. As is customary in DB plans, benefits are determined by age, years of service, and final salary. These plans provide a variety of benefits including disability, death and surviving spouse benefits. While many sector funds cap benefit levels, in effect applying a policy of redistribution based upon sector-wide salary levels, corporate pension funds tend not to cap benefits to the same extent. The value of offered benefits vary between plans, depending upon corporate and sector wage levels. Similarly, there are significant variations in employer and employee contribution rates, more often than not depending upon agreements made in the relevant collective bargaining agreements. Furthermore, the government provides tax relief on pension contributions and investment returns, taxing pension benefits as income during retirement. 
The Netherlands is a small country of less than 16 million people and a workforce of about 7.5 million. And yet, in terms of total pension fund assets, by European standards it is one of the largest economies. By virtue of funding regulations, according to the Verzekeringskamer (1999) total pension fund assets were worth about 700 billion Dfl of which 480 billion were managed by sector funds and 210 billion by corporate pension plans. In terms of asset allocation, however, there are some significant differences between sector plans and corporate plans, and between Dutch plans and UK plans. While both types of plans tend to split assets equally between stocks and bonds, on average corporate plans have about 10 percent more assets allocated to these two categories (approx. 35 percent). Both types of funds have significant real estate and mortgage holdings as well as private placements. In should be recalled that UK funds tend to split their assets between stocks (on average about 80 percent), bonds (13 percent), real estate ( 2 percent) and cash (5 percent). Davis (1995) provides greater information and a comparative international analysis of these patterns and trends.

\section{Institutional Structure of Social Solidarity}

Like the UK and Germany, there have been Dutch employer-sponsored pension plans since the middle years of the nineteenth century. But unlike Germany, Dutch pension plans have developed and grown significantly in relation to social security (compare with Borsch-Supan 2000). Therefore it is tempting to suppose that Dutch plans are, in fact, just like Anglo-American pension plans. Here, we might imagine that any apparent differences are a product of continental European history and geography, being slowly erased by time as recent trends in the Anglo-American world come to dominate policy and practice. So, for example, we might anticipate a slow but inevitable transition from DB plans to defined contribution (DC) plans, especially in the corporate sector, and greater interest amongst plan participants in individual savings plans and the international diversification of market-traded securities. ${ }^{4}$ There can be little doubt that the Dutch pension industry is far more knowledgeable about Anglo-American developments and expertise than their German colleagues.

Despite obvious similarities, Dutch pension institutions are described in very different terms from those that would describe the Anglo-American industry. With specific reference to sector pension funds, the Dutch government and defendants in Maatschappij Drijvende Bokken BV have characterised supplementary pensions using 
the concept of social solidarity. While perhaps an elusive concept for an AngloAmerican audience, it could be thought to combine the principles of equality and fraternity with mutual protection and insurance. Equality can be thought to refer to the value of benefits due plan participants and their equitable treatment with respect to other plan participants. Fraternity can be thought to refer to the governance of pension funds, linking collective interests with collective decision making and accountability. Mutual protection and insurance can be thought to refer to risk sharing and risk pooling, preferring the mutual indemnity of risk to the individual purchase of risk-adjusted insurance policies. Using this notion, the Dutch government and defendants sought to distance Dutch pension funds from market principles, and the application of European competition policy.

This definition of social solidarity, relying as it does on secondary concepts related to the history of social democracy, mirrors government policy and is sustained by deep connections to the roots of contemporary Dutch politics (see Goodin et al. 1999 on the political foundations of Dutch social democracy). It also resonates with German notions of the "social market" and can be linked to the French concept of the social contract. More generally, it has also parallels with the mandate of DG Employment of the European Commission in that it refers to the relationship between "social partners" (unions and employer organisations) in markets and society. This last connection will be developed in more detail below, noting the importance of related clauses to be found in the Treaty of Rome. In suggesting these connections, we do not mean to defend an argument in favour of a pan-European social philosophy. To do so would overwhelm the paper and take in a direction unrelated to the project. But there is a considerable difference between Dutch social solidarity and Anglo-American social theory. For instance, Coleman's (1990) treatise on social theory is practically silent about social solidarity, assuming individual interests are the primary building blocks behind collective action and institutional organisation. ${ }^{5}$

To illustrate, consider the four building blocks of social solidarity relevant to Dutch pensions policy. A remarkable aspect of the Dutch system is the near-universal coverage rates within sectors offering supplementary pension benefits. Not only are employees required to participate in employer-sponsored pension plans, employers are required to participate in multi-employer sector plans unless they offer their own plans paying benefits at least equal to, and preferably superior to, the relevant sector plan. In the ECJ case Maatschappij Drijvende Bokken BV a firm objected to being 
required to participate in the sector pension plan. Like a number of other companies in other sectors, it argued that it had a right to make alternative arrangements (in this instance, with an insurance company). When challenged, the sector plan was able to invoke a government mandate to sustain its claim for compulsory membership, drawing upon a state-protected agreement by employer and employee sector representatives in the early 1950s. Furthermore, the sector plan's decision was deemed final and binding. There are no avenues for an independent review of the sector plan's decision on this matter (or in virtually any other matter).

If compulsory membership is one building block of social solidarity, the second is equal representation of employers and employees on the boards of Dutch sector and corporate pension plans. These boards and their constituent members act on behalf of plan participants and beneficiaries, being legally responsible for their decisions regarding the administration and management of the plan and the prudent investment of pension plan assets. For readers familiar with the powers of AngloAmerican pension plan trustees, this arrangement is consistent with the evolution of Anglo-American trust law and statute (Langbein 1997). Though not as common in the Anglo-American world, in the US there are many small jointly-trusteed multiemployer pension plans in industrial crafts such as plumbing, electrical work, and the construction trades. Dutch pension boards have wide powers consistent with their responsibility for the integrity of sector plans. Furthermore, board membership is often congruent with the board membership of "captive" financial services organisations, and may also overlap with the membership of the boards responsible for sector-based collective bargaining. The institutions and practices of collective bargaining permeate the structure and management of Dutch sector and corporate pension funds.

A third element underpinning social solidarity has to do with the determination of benefit levels. As noted above, sector plan benefits are set in accordance with sectoral compensation standards; there are significant differences between sector plans in terms of the value of their benefits, reflecting the relative place of sectors in the national, EU and global economies. Sectors dominated by industries characterised by high value-added per unit produced have higher benefit levels and a wider range of benefits than those industries operating at the low-wage margins of the global economy. Within sectors, however, benefit levels are standardised between firms and between workers. Firms within the sector indemnify 
one-another with respect to the risk of default on their pension obligations just as individual participants indemnify one-another with respect to the risks of death and disability (for instance). Neither firms nor individuals pay risk-adjusted premiums. Pension benefits are, in effect, averaged across age groups and across firms for the benefit of all even if, in some situations, specific firms and workers may have a claim for special treatment.

With respect to offered pension and insurance benefits, there is no scope for competition between firms within sectors. Furthermore, in accordance with the yearto-year and long-term financial integrity of their plans, pension boards set standard contribution rates. But notice the determination of wage and pension benefits are the responsibility of sector-wide collective bargaining processes. Likewise, allocation of the relative shares of pension plan contribution rates between employers and employees is also left to collective bargaining. Three factors impinge upon the determination of benefit levels and the allocation of contribution burdens. As noted above, compensation is closely related to the value of output which, in turn, is related to labour productivity and the accumulated capital stock). In many industries there are incentives to set benefits and allocate contribution rates in ways that would sustain long-term competitiveness. Second, in industries dominated by a few large firms and linked networks of smaller firms, economic interests may be thought more homogeneous than sectors not so organised. Third, by implication, there are informal mechanisms that protect participating firms and workers from exploitation by those that dominate the collective bargaining process.

To summarise, compulsory membership of sector plans denies the possibility of firms and individuals defecting from the plan. Joint representation in the collective bargaining process and on sector-wide pension boards is thought to dampen inter-firm rivalry, and may sustain the long-term value of pension and insurance benefits. Mutual indemnification of risk encourages collective responsibility and collective solidarity, limiting the possibility of exploitative standard setting by those who control the institutions of social solidarity. Ideally the legal independence of pension boards insures the financial integrity of sector pension funds while their close relationship to the collective bargaining process ensures benefit standards and contribution rates consistent with economic circumstances. In these ways, advocates of the Dutch model argue that the national institutions of social solidarity properly regulate the risks of selection bias and moral hazard. 


\section{Pension Fund Governance and Performance}

Dutch pension plan participants and beneficiaries are the "principals" of their plans. Their agents are board members who are appointed by their employee representatives (unions) and plan sponsor employers. In turn, board members monitor and control the managers of plans. As board members, they have a legal duty to ensure all current and expected obligations are met in full. Notwithstanding this principle, board members also represent the considerable economic interests of unions and plan sponsors in the costs and performance of their pension funds. Nominally, Dutch pension plans are non-profit mutual insurance institutions. Any accumulated net returns over and above current and expected liabilities are identified as a "surplus" rather than a "profit", the distinction being driven by deeply held beliefs in the difference between firms based upon private property rights and collective associations based upon mutual agreement. Nonetheless, there is considerable debate in The Netherlands and elsewhere over the proper disbursement of surplus returns. While plan sponsors and current employees have an unmistakable interest in using any surplus to reduce contribution rates, retiree groups have a vocal interest in added benefits and the prompt adjustment of benefits to increases in real wages.

In theory, it can be argued that (non-profit) sector pension plans are more costefficient than competing (for profit) insurance companies. Because of the compulsory nature of firm and worker participation in sector plans, there is little need for advertising and marketing. Plan participants are enrolled at the participating firm, obviating the need for a large sales-force or telemarketing site. The costs of administrating deductions are not trivial. But in the first instance these costs are borne by the firms rather than sector funds. Since it is very unusual for a firm and its workers to leave a sector plan, there are practically no switching costs on either side (plan sponsor or sector plan). Perhaps as importantly, the use of standardised as opposed to individualised risk-adjusted benefit and premium schedules imply low average per-unit processing costs. At the same time, this may also mean limited services for participants and little in the way of a service-culture in the plan. Finally, the over-arching non-profit mandate may mean lower compensation rates for board members compared to their colleagues in insurance companies as well as compressed internal salary structures referencing sector salary norms rather than the salaries accorded similar functions in the financial services industry. ${ }^{6}$ 
While the reality of these cost advantages has been disputed by the insurance industry, it appears that confidential government inquiries have confirmed their existence. For the Dutch government, concerned to shift the burden of retirement financing to pension plans in a socially equitable manner, the preferential status of sector plans has the twin virtues of cost-efficiency and social inclusion. ${ }^{7}$ Even so, there remain two substantial objections to the monopoly status of these institutions. The first has to do with the robustness of the claimed distinction between collective associations and firms. Does the non-profit mandate make such a difference that competition issues can be obviated in favour of social solidarity? The second issue bears upon the economic performance of sector plans. If their costs per unit are less than competing insurance companies, it does not follow that their investment performance is similarly superior. In fact, the net performance of a sector fund could be less than a competing insurance company. If so, then the monopoly status of sector funds would amount to a subsidy to those participating firms and their workers who would otherwise pay higher premiums for coverage from the insurance industry. These two issues can be combined into a common question: how significant is pension fund governance with respect to their functional performance?

It is difficult to answer this question with empirical precision. Though many funds use cost and performance benchmarks for internal management purposes, the costs of Dutch funds with respect to one-another and with respect to the insurance industry are difficult to obtain. ${ }^{8}$ As for investment performance, the limited available information is problematic. As is well-known, a major component of investment performance is the initial allocation of assets between asset classes. Over the 1990s, investment strategies driven by equities would have ceteris paribus delivered higher returns than strategies driven by bonds. Asset allocation, however, is determined by a variety of factors including the underlying profile of expected liabilities. Therefore, we must be cautious in drawing conclusions from the available data. ${ }^{9}$ In Figure 1 we report Dutch pension fund investment performance by type (corporate and sector) for year-end 1998 (provided by VB). On average, sector plans out-performed corporate plans (13.3 per cent against 12.8 per cent). But the difference was slight given the higher dispersion of returns amongst corporate funds. Further more, the distribution of returns within the two types of funds was very similar. It was difficult to draw distinctions in terms of the distribution of returns according to fund type, fund size or the pattern of asset allocation. 


\section{Ownership and Governance}

As is well appreciated, the Anglo-American corporation is characterised by "a separation of ownership and managerial control" (Viscusi et al. 1995, p. 456). Ownership is diffuse with many shareholders holding "a small or negligible percentage of shares." Managers control the firm, relying upon implied and delegated powers over a wide number of topics (Roe 1994). ${ }^{10}$ Discipline is based upon the market for corporate control. Boards of management can be deposed, managers penalised by the sale of the firm, and bankruptcy declared by disenchanted creditors. Theoretically, the over-arching behavioural imperative is profit maximization and, in turn, shareholder value. Of course, there is considerable debate over the efficiency of market discipline, and the degree to which profit maximization as opposed to managers' vested interests rule decision-making (Jensen 1993). By convention, continental systems of corporate governance are deemed "different": shareholder control is believed more direct, being in the hands of inter-locking networks of large investors not the market for corporate control (see Hopt at al. 1999 for an exhaustive cross-country survey). Even so, problems of ownership and control loom large albeit less understood (Jenkinson and Ljungqvist 1999).

This account of the Anglo-American corporation suggests commonalities with Dutch sector pension plans. More often than not both are characterised by diffuse ownership. In sector plans, it could be reasonably argued that "owners"” (participants and beneficiaries) voice in the management of the plan is muted by poor co-ordination amongst large numbers of individual "shareholders". The affiliation of workers through their sponsoring firms implies competing inter-firm cost profiles, adding to the problem of coherence. A common labour union is one means of routinely coordinating the interests of "owners". Even then unions have their own interests in the participating firms and in the performance of the over-arching pension plan (see below). In practice, there are no dis-interested firm or worker representatives. Managers are confronted, as they are in the modern corporation, by boards of directors riven with conflicting interests yet nevertheless required to manage those conflicting interests on behalf of shareholders (see Eggertson 1990 for a general argument along these lines).

It might be protested that as social solidarity is the dominant value, problems of co-ordination and coherence would be less severe than in the modern corporation. However, social solidarity may not be so virtuous or so laudable. Consider the 
following possibilities. In a sector characterised by long-term economic decline, the representatives of older workers may, in effect, capture policy making. Their interests in early retirement and a high rate of income replacement may not be consistent with younger workers' interests in capital investment and long-term growth. Second, in sectors characterised by large numbers of relatively unorganised smaller employers, workers' representatives may dominate pension board decision-making. By default, relatively unco-ordinated employers may allow employee representatives to protect workers' current income and long-term benefits by shifting the burden of contribution rates to employers. The temptation exists to spread the benefits of pension income while concentrating their costs. Third, none of the institutions of social solidarity may have the capacity to affect, or a compelling interest in monitoring, the costs of pension and insurance benefits. The legal independence of pension board members may be so pronounced that they are able to shift the added costs of institutional inefficiency to the collective bargaining process. Given the power of pension boards over firms in sector plans, the costs and risks of board decision making are inevitably transferred to individual firms and their workers (moral hazard). ${ }^{11}$

\section{Sector Funds as Financial Conglomerates}

There is another, related problem of pension fund governance. So far, we have been silent about sector funds' purchase of financial services. This is not the occasion to go into detail about the nature and scope of pension funds financial service needs. In Clark (2000, ch. 4), there is an extensive treatment of this issue based upon the AngloAmerican industry, entirely relevant to the Dutch pension fund system. It is sufficient to observe that pension funds normally consume a wide variety of financial services, ranging from actuarial services, custodial management and banking services to advanced investment management services. Over the past ten years, it has become apparent in the Anglo-American pension world that there are considerable scale economies in the provision of many types of financial services (Berger et al. 1999). Witness the use of companies such as State Street of Boston as the custodial managers of the flow of funds between various internal and external service providers. Many of the largest Anglo-American funds combine internal service provision with external sub-contracting, utilising consultants to act as gate-keepers between the boards of pension funds and the financial services industry. Not surprisingly, issues of trust and comparative cost are important in the assessment of competing service providers (Clark 2001). 
In the Anglo-American pension world, the governance of these fund-to-market relationships is a vital component of pension fund performance (Ambachtsheer and Ezra 1998). However, in the Dutch model many sector funds appear to be financial conglomerates in their own right or the shareholders with other pension funds in mutually-owned financial firms. Many of the largest funds operate financial firms from their administrative offices, using boards of directors drawn from the fund's own board of directors. In effect, fund directors are the representatives of (first) plan participants, (second) plan sponsors or unions, and (third) the funds in wholly-owned financial subsidiaries. It is also not unusual for the managers of sector funds to act as the managers of services provided by these "firms". Furthermore, a significant number of smaller sector funds are the exclusive shareholders in large financial conglomerates, offering the whole range of needed financial services (from custodial services to insurance and investment management). Boards of management are drawn from the participating funds. These captive firms then sell to the constituent funds services required for the management of the funds, based upon purchasing policies or protocols set by funds' board of directors and implemented by funds' managers.

By Anglo-American financial standards, these are unusual ownership patterns and relationships. Indeed, given the heretofore separation between different types of financial industries owed to the Glass-Steagall Act, and in effect copied by other Anglo-American countries, it is hard to identify equivalent US and UK institutions (Bentson 1990). In defence of these arrangements, sector fund representatives argue that vertical integration is more cost-effective than the purchase of financial services from market vendors. As noted above, the internalisation of service functions allows fund managers to strip-out vendor marketing costs, the switching costs of moving mandates between vendors, and the transaction costs associated with contracts and their enforcement. Because of non-profit mutual ownership, profit is less important than meeting the costs of service provision (including the costs of depreciation and capital replacement). Similarly, because salary costs are managed with respect to sectors' standards and norms rather than the global market for financial services, salaries tend to be compressed. At the same time, because funds' managers have multiple overlapping responsibilities, salaries can be set higher than would otherwise be justified by reference to his or her sector fund functions.

These ownership relationships between funds and their firms combined with incentives to minimize changes to contribution rates also encourages sector funds and 
their plan sponsors to standardise internal reporting functions: accounting systems, custodial systems, and investment products and management regimes. There are significant savings to be had from standardisation; increasing returns to scale at lower per unit cost thresholds. As well, standardisation locks-in all parties' commitment to the functional design and governance of the whole system of financial services. If defection from sector plans were legally possible, for many plan sponsors it would be very expensive given the evolution of these complex functional and information systems. Notice, however, that standardisation has its limits. Legal requirements that plans actuarially match assets with liabilities means that board members and their financial service firms must ensure that, for example, investment regimes are tailored to the particular liability profiles of each plan. Each participating plan within these financial institutions requires an investment strategy. Even so, the largest pension institutions have developed sets of investment products allowing for the pooling of assets between plans while maintaining common reporting systems capable of discriminating between the assets of constituent plan sponsors.

In fact, the largest Dutch pension institutions have come to replicate many of the reporting systems of competing global investment management firms. For instance, the format used by firms like Flemings, J P Morgan, and Schroders to report on the context, goals, portfolio structure and performance of their various investment products is very familiar to Dutch sector funds. Reporting on the volume of equity investment products' assets, their largest holdings, and the benchmarks used to assess comparative performance are features in common with the Anglo-American market for investment management. As such, there is clearly a temptation amongst the largest sector funds-firms to mimic the procedures of their market rivals. In this sense, the Dutch sector funds are less insulated from the global financial services market than often realised. Indeed, as these funds match and mimic the services and reporting systems of global investment groups, there is a temptation for these fundsfirms to seek more members, to market their services beyond the statutory borders of the sector. Thus, some funds-firms have sought to acquire related financial products, health insurance products and even banking services with existing or potential retail bases in the Benelux countries. At the margin, Dutch funds-firms are increasingly rivals in the European financial services industry.

Sector funds as financial institutions still need external specialised expertise. The design of financial systems is increasingly sophisticated, being driven by 
consultants with close relationships with advanced software companies. As well, all pension funds require actuarial services recognised and respected by Dutch insurance regulators. For Dutch funds-firms it is neither cost effective nor is it legally possible in many cases for these institutions to hire and retain such specialised expertise. Thus many sector funds have come to rely upon selected external service providers, often developing long-term relationships with those firms able to appreciate the complex governance and ownership patterns associated with these institutions. Inevitably, trust relationships are the dominant rationale behind sector funds' own purchase of marketbased financial services. Alternatively, as global financial groups have arrived in Europe bent on learning more about the particular institutional structure of fundsfirms, trust relationships have been increasingly threatened by market relationships.

\section{Financial Structure and European Competition}

In Maatschappij Drijvende Bokken BV, the ECJ was petitioned by the Dutch high court to rule on the legality of sector funds' exclusive domain. Specifically, Article 85 (competition in the common market), Article 86 (abuse of dominant market position) and Article 90 (states' grants of exclusive rights) were identified by the plaintiffs as grounds for objecting to the monopoly status of Dutch sector pension funds. ${ }^{12}$ This case was one of a group of three related cases, brought by firms deemed to be within the domain of existing sector funds but seeking to make alternative arrangements for the provision of pensions and insurance with external insurance companies. In Albany, the textile sector fund (with about 6,000 participants) had required the firm to become a member of the fund, denying the right of the firm to provide equivalent or superior benefits. In the headline case Maatschappij, the firm had been incorporated into the dock workers sector fund (about 14,000 participants) in the early 1991 by virtue of a government decree covering all similar firms. And in Brentjens, the building materials sector fund (about 200,000 participants) had incorporated the firm within its domain, denying the validity of existing arrangements with an insurance group.

In all three cases, the insurance industry was excluded from the provision of pension and insurance benefits to individual firms. Prior to initiating court proceedings, two of the three firms affected had appealed to their sector funds for exemption, and had then appealed to the Dutch Insurance Board to over-turn the sector funds' negative decisions. Although the Insurance Board had recommended in 
the Albany case that the fund reconsider their decision, the fund refused. The ECJ was asked to rule on the legality of these arrangements, putting in play the status of national social solidarity in relation to EU competition policy--the status of national solutions to the demographic bomb given the over-arching interest of all EU governments in an integrated market for financial services.

Against hopes and expectations in the Anglo-American financial world, the ECJ ruled that the Dutch system was legitimate invoking Article 3(1)(g) and (j) of the Treaty of Rome and Article 1 of the Agreement on Social Policy (OJ 1992 C 191). ${ }^{13}$ Basically, the ECJ ruled that the objectives of EU competition policy had to be balanced against objectives of economic and social cohesion (Article 3(1)(j)) and dialogue between the social partners (labour and management) (Article 1, Agreement on Social Policy). The advantages of sector-wide social solidarity in matters pertaining to pensions and insurance were explicitly linked to the EU treaty and its objectives of sustaining the collective bargaining process. The Court noted the importance of risk sharing and mutuality in setting standard pension benefits within sectors and across participants, distinguishing their decision in this set of cases from previous decisions that had favoured the claims of the insurance industry. ${ }^{14}$ At the same time, the court held that Dutch government regulations allowing sector funds with the agreement of the relevant social partners to petition for compulsory affiliation did not contravene EU competition policy. Even though sector funds were properly regarded as economic undertakings, the social objectives of these institutions were such that issues like competition and the abuse of dominant position could be set-aside (for the moment).

The narrowest version of competition policy suggests that its only proper objective is economic efficiency (hence maximum consumer welfare) (Hay 1993, p. 2). From this proposition, arguments can be made regarding various kinds of market behaviour, including individual (predatory) and collective (collusive) pricing practices with respect to apparent patterns of resource allocation (Rees 1993). Inevitably, this proposition relies upon the analysis of market structure, including the actions of existing market participants in relation to actual or potential new market entrants. In general, there is a presumption against any actions that result in or sustain market dominance; in turn, there is a presumption in favour of competition and the rights of competitors to enter markets (see Faull and Nikpay 1999, ch. 1). Article 85 prohibits any "agreements", “decisions" and "concerted practices" amongst economic 
undertakings that would adversely affect competition in the European common market. It specifically prohibits price fixing, and other trading agreements that would exclude or harm competition. Article 86 prohibits undertakings from using their market position to place existing or potential competitors at a disadvantage, thereby affecting the welfare of consumers. Article 90 prohibits member states from granting undertakings exclusive rights of market access to selected undertakings, thereby limiting indirectly or directly competition.

While it may appear that the Dutch insurance industry had reasonable claims against the monopoly of sector pension funds, it should be recognised that EU competition policy is not an end in and of itself. According to Schaub (1998), Director General of DG Competition, EC competition policy is best understood as a means to an end. That is, the achievement of objectives enshrined in the Treaty of Rome including the creation of a single market, convergence between member states in economic performance, and the promotion of social cohesion and mutual respect amongst the social partners. Thus EU competition policy is inevitably caught-up in the whole fabric of policy making, and the balancing of contending political objectives. This does not mean that the competition directorate is ultimately responsible for balancing or adjudicating claims from outside their statutory mandate. As acknowledged by competition policy makers, given the anti-competitive actions of many market agents and many governments, their role is to advocate solutions that have as their objective greater EU market efficiency. ${ }^{15}$ The role of ECJ adjudication is to balance programmatic objectives against the legitimate claims of other overarching objectives contained in the Treaty of Rome and its progeny.

In the foregoing discussion, we have posed an argument to the effect that European competition policy should not be thought to inevitably "trump" national social objectives. More will be made of this point below. Before doing so, however, it is important to acknowledge that within the EU competition policy "community" there are two related arguments that the geographical scope of the market for financial services is, in any event, smaller (national and local) than the market for manufactured goods (European and global). On one side there is a positive argument, suggesting that this is in fact empirically true. On the other side there is a normative argument that the market for financial services should be treated as if it is geographically smaller than Europe given local preferences, competence, and the flow of information. In effect, it might be suggested that European competition issues with 
respect to national systems of financial services have less significance than otherwise assumed. Therefore the Dutch supplementary pensions model warranted protection from the ECJ by virtue of the assumed geographical scope of European competition within the financial services industry.

Sapir et al. (1993) advanced the empirical argument, suggesting that imperfect competition dominates the European market for financial services. They began by arguing that capital investment per unit produced is lower in services than in manufacturing and that the switching costs between alternative uses of capital are also lower in services than in manufacturing. More specifically they suggested that the market for financial services does not meet standard tests of contestability. Because of the distinctiveness of local needs there are few potential entrants; because reputation is an essential ingredient in assessing the value of potential competitors, established relationships dominate local markets; and because locating and servicing customers is such an labour-intensive activity, few potential competitors are capable of raiding established markets. Sapir et al. (1993) also argued that dispersed crossborder transactions from remote sites of production are very difficult because of the nature of financial products: they are information intensive and characterised by informational asymmetries favouring selling agents over potential customers. Market access relies upon established relationships to overcome the distrust of potential clients. Therefore, local reputation is a significant barrier to (pan-European) entry.

These empirical claims about the geography of the financial industry can be disputed. For instance, the economies of scale apparent in processing financial products and services are such that producers must re-currently invest in information technology of all kinds to remain competitive. Indeed, there is evidence that mergers and acquisitions in the financial services industry have been driven by the need to spread the costs of information-processing investment, thereby creating a global industry (Clark 2000, ch. 5). Further more, it seems very unlikely that these types of investments can be switched between alternative uses, given their rapid obsolescence and disposal as junk. In this context, information technology is better treated as a sunk cost than as a fixed cost. This point is put in the previous section of the paper, suggesting that funds-firms have evolved as multi-functional financial conglomerates in part because of the economies of scale to be had in standardising benefit, accounting and reporting systems between complementary functions and between plan sponsors within sectors. While there may be few competing financial service 
firms willing or able to match the configuration of those internal sector-wide systems, this does not mean that the industry can only reap economies of scale from geographical and vertical concentration. ${ }^{16}$

On the issue of information asymmetry, Sapir et al. (1993) can be together with those who argue the normative case. For instance, Rees and Kessner (1999) amongst others would argue that given the sophistication and complexity of many retirement benefit systems, the potential for exploiting customers' ignorance is so significant that overall consumer welfare is best protected by limiting the potential of "hit-and-run" competition. No doubt some firms would find value in opting-out of sector-wide plans, principally because they are either not yet incorporated into sectorwide systems or are subject to competitive pressures that require benefit discounting. The so-called UK pensions "mis-selling" scandal is evidence for the real costs to individuals and society involved in promoting opting-out of systems of social solidarity. There remain, however, industry observers who dispute the significance of information asymmetries. Furthermore, the rapid development of cross-border sales of financial products utilising internet technology and voice-based remote calling centers suggests that many consumers are willing to take the risk of information asymmetry if the product is significantly cheaper that conventional local relationshipbased modes of transacting.

But notice neither the empirical nor the normative counter-arguments need undercut the Dutch government's policy of protecting sector-wide pension plans from external competition. The goals of comprehensive coverage and equitable retirement income are probably best achieved by compulsory affiliation. But sector plans are vulnerable to claims that the funds-firms' vertical integration of financial transactions into captive financial firms go well-beyond achieving the substantive goals of the pension system. In this system of funds and firms the consumers of financial products are not individual beneficiaries but skilled financial professionals, the agents and representatives of plan beneficiaries. Given their experience in global and European financial markets it is difficult to sustain any argument that these "consumers" of pension fund financial services need protection from the European financial services industry by granting a monopoly over the provision of those services. This does not necessarily mean that the global and European financial services industries would deliver cost-effective products consistent with the sector plans' benefits of common systems of management and reporting. Our argument is that, absent fund governance 
transparency and accountability, the only plausible test of the cost efficiency of fundsfirms is direct competition.

\section{Conclusions}

The Dutch model of retirement income has been promoted as an important option for the future of European pensions. It provides for equitable income redistribution, comprehensive coverage and funded supplementary pensions. And it provides for a partnership between the state and the market in determining retirees' total retirement income. Notwithstanding the slow discounting of the Dutch state's share of total retirement income, many commentators argue that the Dutch model has been a significant success in accommodating various social and economic interests in the context of outstanding economic growth (see OECDa 1998 and Goodin et al. 1999). Not only have pillar II coverage rates remained high over the past twenty years, the Dutch model has avoided some of the most pernicious aspects of insurance systems including selection bias. Indeed, it is arguable that the often-times compulsory nature of sector-wide pension benefits provides for the long-term welfare of many employees at average rates of compensation above that which could be offered by systems of insurance. In this respect, the economic virtues of social solidarity are significant and deeply implicated with national politics.

For continental Europe, long accustomed to modes of collective decision making involving various stakeholders, the Dutch model also provides an important model for the roles of social partners in the organisation and management of pension fund institutions. As in a number of continental European states, the explicit link between the institutions of collective bargaining or co-determination and the institutions of retirement benefits provides employee representatives a significant role in managing workers' current and future incomes. Moreover, the sector-wide system of benefit levels and their negotiation is deliberately designed to remove inter-firm rivalry from long-term compensation; the system was conceived to achieve a variety of social objectives including the equitable standardisation of intra-sector retirement income. In this respect, retirement income is an integral element of the social market much admired by some UK commentators; see Hutton (1996). In their Maatschappij Drijvende Bokken BV opinion, the ECJ distinguished insurance systems from systems of social solidarity in relation to these objectives of social policy. 
In this paper, we have sketched the elements of the Dutch model, concentrating on the governance of pension fund institutions. In doing so we have noted the relationship between pillar I and pillar II pensions, as well as the underlying social goals that sustain Dutch government policy. These social goals should not be ignored, notwithstanding the subsequent emphasis of the paper on matters related to governance and competition. It would be much too simplistic to reduce such goals to mere political interests, in some way suggesting these issues are trivial in relation to competition policy. While some academic analysts may wish competition policy to be shorn of its connections with social policy, in the EU as in many other jurisdictions competition policy (and its goal of economic efficiency) is a means to an end not the end in and of itself. Therefore there are legitimate reasons to celebrate the distinctiveness of the Dutch system, rather than presume that its design and organisation as a set of financial institutions is necessarily antagonist to EU competition policy. ${ }^{17}$

On the other hand, we have also argued that the ECJ decision mistook form for substance. The court recognised the virtues of social solidarity in determining Dutch pension coverage rates and benefit levels, an important conclusion given the possible disadvantages of pension systems offered by potential competitors from the insurance industry. While doing so, the court also properly recognised that sector pension funds are functionally economic undertakings. Following EU precedent, just because an entity is a not-for-profit organisation or a mutually-owned organisation does not mean that it falls outside of the scope of competition policy. But notice our argument has been that the court failed to take its functional logic far enough. The court seems to have assumed that pension funds are simply the representatives of beneficiaries' interests, ignoring the important financial institutions owned and operated by those funds. Most importantly, the court failed to appreciate the hidden costs of sector fund economic organisations - that is, the potential costs associated with the vertical integration of funds' financial services borne by pension fund beneficiaries, plan sponsors and/or participating employees. There is a real risk of moral hazard; that is, the costs and risks of organisation transferred to those without an adequate voice in its operation.

Most importantly, the Dutch model may be a means of holding at bay global competition in European financial services. It is not clear that the protection from market competition afforded Dutch sector funds by virtue of the ideal of social 
solidarity should extend to protecting pension funds' captive financial institutions. In theory, sector-wide pension funds could maintain their interests in social solidarity while decentralising to the market the purchase of financial services. Of course, a counter-argument would be that internalisation of transactions combined with lower overhead costs of this particular form of organisation would effectively exclude competition from the market. However, embedded in this argument are a variety of other possibilities. One is that the internalisation of transactions may mask crosssubsidies between financial service functions, sheltering some functions more efficiently provided by the market while draining the surplus of other functions that could add value to plan sponsors and plan participants. Another possibility is that these funds-firms are actually the creatures of their administrators and managers, providing opportunities for patronage and extra income (rent). This type of arrangement may be a vital ingredient in lowering overall costs of production - there may be mutually-realised benefits not available to plan agents from the market. But, it is entirely possible that funds-firms are actually more expensive than the market for financial services.

The problematic issues here are twofold: agency and transparency. It is difficult for firms and their employee participants to judge fund-firm performance. If this kind of information is collected and set against appropriate bench-marks for comparison, it is rarely made available outside of sector funds' management boards. Moreover, it is rare for funds-firms to produce costs of servicing data separate from the bundle or integrated web of internal transactions. And even if such data was produced, it is very difficult to judge performance because of the isolation of the global financial services industry from the Dutch pension funds industry. While cost data is available from many of the largest global financial services providers, the tendency to integrate participating firms-funds into specific accounting and reporting systems suggests there would be very high entry costs for any external financial firm that was to claim a particular function. In this respect, the long-term relationships between the managers of funds-firms and their actuarial consultants are important barriers to entry. Both have vested interests in sustaining their distinctiveness with respect to global market standards of financial service provision.

If transparency is a problem, so too is agency. There is a danger in compulsory affiliation systems that individual plan sponsors and their participants become the captive "owners" of funds-firms. This is especially a risk for smaller 
firms, in sectors dominated by dispersed "ownership" and concentrated union representation. The ECJ has failed to consider the importance of a legitimate appeal process underpinning compulsory affiliation. While important social goals are accomplished by social solidarity, the lack of an adequate appeals process leaves "owners" with few options. The apparent equation made between co-determination and pension fund governance confuses one set of interests (stakeholder representation) with rather different interests (efficient fund-firm governance). This may not have been so important a problem in years gone by; limited international competition in many sectors of the Dutch economy may have effectively sheltered these arrangements from close scrutiny. But with the increasing inter-penetration of global, EU and national competitive pressures, many plan sponsors and their participants have an interest in the costs of pension fund governance not only the benefits of sector funds.

In this respect, the Dutch model is a partial model. Its' solution to the problem of selection bias has created potentially significant moral hazard problems. In turn, there are also potential problems of cost efficiency. If EU competition policy is to be silent on these issues, other agencies and organisations must look more closely at reforming the governance of European pension funds and related institutions. In this respect, we note that De Ryck's (1999) report on European pensions endorsed by DG Internal Market argues for reforming pension fund boards. Drawing upon recent developments in the US mutual fund industry (Brennan et al. 1999) and related concerns raised in the UK in the wake of the Maxwell scandal, De Ryck suggested that boards be properly composed of a significant majority of independent trustees or members. While a spontaneous market for pension-related financial services is unlikely in the near future, the threat of defection by disenchanted firms is an increasing likelihood notwithstanding the apparent inability of plan sponsors to leave compulsory sector-wide funds. ${ }^{18}$

\section{Endnotes}




\section{References}

Ambachtsheer, K. and D. Ezra. 1998. Pension Fund Excellence: Creating Value for Stakeholders. New York: Wiley

Arrow, K. J. 1984. Insurance, risk, and resource allocation. In Collected Economic Papers Volume 4: The Economics of Information. Cambridge MA: Harvard University Press, pp. 77-86

Bennett, P. 2000a. Anti-trust? European competition law and mutual environmental insurance. Economic Geography (forthcoming)

Bennett, P. 2000b. Mutuality at a distance: risk and regulation in marine insurance clubs. Environment and Planning A 32, 147-63

Bentson, G. J. 1990. The Separation of Commercial and Investment Banking: The Glass-Steagall Act Revisited and Reconsidered. New York: Oxford University Press

Berger, A. N., R. S. Demsetz, and P. E. Strahan. 1999. The consolidation of the financial services industry: causes, consequences, and implications for the future. Journal of Banking and Finance 23, 135-194

Blomsma, M. and R. Jansweijer. 1997. The Netherlands: growing importance of private sector arrangements. In Enterprise and the Welfare State edited by M. Rein and E. Wadensjo. Cheltenham: Edward Elgar, pp. 220-65

Boldrin, M., J. J. Dolado, J. F. Jimeno and F. Peracchi. 1999. The future of pensions in Europe. Economic Policy 29, 289-321

Borsch-Supan, A. 2000. A model under siege: a case study of the German retirement insurance system. Economic Journal 110, F24-F45

Brennan, J. J., D-M. Driscoll, P. G. Haaga, M. H. Johnson, W. M. Lyons and G. C. McDonough. 1999. Enhancing a Culture of Independence and Effectiveness: Report of the Advisory Group on Best Practices for Fund Directors. Washington DC: Investment Company Institute

Budd, A. and N. Campbell. 1998. The roles of the public and private sectors in the UK pension system. In Privatizing Social Security edited by M. Feldstein. Chicago: University of Chicago Press, 99-134

Clark, G. L. 1998. Stylised facts and close dialogue: methodology in economic geography. Annals, Association of American Geographers 88, 54-78

Clark, G. L. 2000. Pension Fund Capitalism. Oxford: Oxford University Press

Clark, G. L. 2001. Pension systems: a comparative perspective. In The International Encyclopedia of Business and Management: IEBM Handbook of Economics edited by W. Lazonick. London: Thompson (forthcoming) 
Coleman, J. S. 1990. Foundations of Social Theory. Cambridge MA: Harvard University Press

Davis, E. P. 1995. Pension Funds: Retirement Income Security and Capital Markets. An International Perspective. Oxford: Oxford University Press

Davis, E. P. 1996. International experience of pension fund reform and its applicability to The Netherlands. Working Paper 11. London: Birkbeck College, University of London

De Burca, G. 2000. Re-appraising subsidiarity's significance after Amsterdam. In State of the European Union 5: Risks, Reform, Resistance and Revival edited by M. G. Cowles and M. Smith. Oxford: Oxford University Press (forthcoming)

De Ryck, K. 1999. Rebuilding Pensions: Security, Efficiency, Affordability. Brussels: Pragma Consulting

DeYoung, R., K. Spong and R. J. Sullivan. 1999. Who's minding the store? Motivating and monitoring hired managers at small, closely held firms: the case of commercial banks. WP-99-17. Chicago: Research Department, Federal Reserve Bank of Chicago

Disney, R. 2000. Crises in public pension programmes in OECD: what are the reform options? Economic Journal 110, F1-F23

Edey, M. and J. Simon. 1998. Australia's retirement income system. In Privatizing Social Security edited by M. Feldstein. Chicago: University of Chicago Press, 63-97

Eggertson, T. 1990. Economic Behaviour and Institutions. Cambridge: Cambridge University Press

Esping-Anderson, G. 1989. The Three Worlds of Welfare Capitalism. Oxford: Polity Press

Evans, A. 1998. European Union Law. Oxford: Hart Publishing

Feldstein, M. 1998. Introduction. In Privatizing Social Security edited by M. Feldstein. Chicago: University of Chicago Press, 1-29

Gardiner, K. 1999. De-fusing the demographic bomb. Special Economic Study. London: Morgan Stanley Dean Witter

Goffee, R. and G. Jones. 1998. The Character of a Corporation. New York: HarperCollins

Goodin, R., B. Headey, R. Muffels, and H-J. Driven. 1999. The Real Worlds of Welfare Capitalism. Cambridge: Cambridge University Press

Greenwich Associates. 1999. Investment Management in The Netherlands: Market Dynamics Tables. 8 Greenwich Office Park, Greenwich, CT 
Gruber, J. and D. Wise. 1997. Social security programs around the world. Working Paper 6134. Cambridge MA: National Bureau of Economic Research

Hay, D. 1993. The assessment: competition policy. Oxford Review of Economic Policy 9 (2), 1-26

Helm, D. and T. Jenkinson. 1997. The assessment: introducing competition into regulated industries. Oxford Review of Economic Policy 13 (1), 1-14

Hopt, K. J., H. Handa, M. J. Roe, E. Wymeersch and S. Prigge. Eds. 1999. Comparative Corporate Governance: The State of the Art and Emerging Research. Oxford: Oxford University Press

Hutton, W. 1996. The State We Are In. London: Jonathan Cape

Jenkinson, T. and A. Ljungqvist. 1999. The role of hostile stakes in German corporate governance. Working Paper 99-FE-02. Oxford: Said Business School, University of Oxford

Jensen, M. 1993. The modern industrial revolution, exit, and the failure of internal control systems. Journal of Finance 48, 831-880

Leibfritz, W., D. Roseveare, D. Fore, and E. Wurzel. 1995. Ageing populations, pension systems and government budgets: how do they affect savings? Working Paper 156. Paris: Economics Department, OECD

Neven, D., P. Papandropoulas, and P. Seabright. 1998. Trawling for Minnows: European Competition Policy and Agreement Between Firms. London: Centre for Economic Policy Research

OECD. 1998a. OECD Economic Survey 1997-1998: Netherlands. Paris

OECD. 1998b. Maintaining Prosperity in an Ageing Society. Paris

OECD. 1999. OECD in Figures: Statistics on Member Countries. Paris

Olson, M. 1965. The Logic of Collective Action. Cambridge MA: Harvard University Press

Orszag, P. and J. Stiglitz. 1999. Rethinking pension reform: ten myths about social security. Mimeo. Washington DC: World Bank

Ploug, N. and J. Kvist. 1996. Social Security in Europe: Development or Dismantlement? The Hague: Kluwer Law International

Pratt, J. and R. Zeckhauser. Eds. 1986. Principals and Agents. Boston: Harvard Business School Press 
Prins, F. 1999. Introduction to the Dutch pension system. Rijswijk: Vereniging van Bedrijfspensioenfondesn (VB)

Rees, R. 1993. Tacit collusion. Oxford Review of Economic Policy 9 (2), 27-40

Rees, R. and E. Kessner. 1999. Regulation and efficiency in European insurance markets. Economic Policy 29, 365-399

Roe, M. J. 1994. Strong Managers, Weak Owners: The Political Roots of American Corporate Finance. Princeton: Princeton University Press

Salaminen, K. 1993. Pension Schemes in the Making: A Comparative Study of Scandinavian Countries. Helsinki: Central Pension Security Institute

Sapir, A., P. Buigues, and A. Jacquemin. 1993. European competition policy in manufacturing and services: a two-speed approach? Oxford Review of Economic Policy 9 (2), 113-132

Schaub, A. 1998. Competition policy objectives. In European Competition Law Annual 1997: Objectives of Competition Policy edited by C. D. Ehlermann and L. L. Laudati. Oxford: Hart Publishing, pp. 119-128

Shaw, J. 2000. The paradox of the 'European polity'. In State of the European Union 5: Risks, Reform, Resistance and Revival edited by M. G. Cowles and M. Smith. Oxford: Oxford University Press (forthcoming)

Stone, D. 1999. Learning lessons and transferring policy across time, space and disciplines. Politics 19, 51-59

Swaan, A. 1998. In Care of the State: Health Care, Education, and Welfare in Europe and the USA in the Modern Era. Oxford: Polity Press

Verzekeringskamer. 1999. Financiele Gegevens Pensioenfondsen. Apeldoorn

Vickers, J. 1997. Regulation, competition and the structure of prices. Oxford Review of Economic Policy 13 (1), 15-26

Viscusi, W. K., J. M. Vernon, and J. E. Harrington. 1995. Economics of Regulation and Antitrust. $2^{\text {nd }}$ Edn. Cambridge MA: MIT Press

Watson Wyatt. 1998. Executive Summary: The World's Major Savings Markets. Reigate

World Bank. 1994. Averting the Old Age Crisis. Washington DC 
Table 1. Size distribution of Dutch sector plans, including total number of participants by size class (000's) for 1994.

\begin{tabular}{|l|c|c|c|}
\hline \multicolumn{1}{|c|}{$\begin{array}{c}\text { SIZE CLASS } \\
(000 \text { 's })\end{array}$} & Number in class & $\begin{array}{c}\text { Total number of } \\
\text { participants }\end{array}$ & $\begin{array}{c}\text { Percent share of all } \\
\text { sectors participants }\end{array}$ \\
\hline$<1.0$ & 12 & 6,769 & 0.2 \\
\hline $1.0-4.9$ & 27 & 69,693 & 2.2 \\
\hline $5.0-9.9$ & 16 & 118,761 & 3.7 \\
\hline $10-49$ & 12 & 215,141 & 6.7 \\
\hline $50-99$ & 3 & 223,438 & 8.0 \\
\hline $100-499$ & 8 & $1,013,817$ & 33.0 \\
\hline$>500$ & 2 & $1,465,918$ & 46.0 \\
\hline & 80 & $3,113,537$ & 100.0 \\
\hline
\end{tabular}

Source: Vereniging van Bedrijfspensioenfondesen, Rijswijk, The Netherlands

Table 2. Size distribution of Dutch corporate and sector pension funds by value of assets (Dfl 1998) and numbers in class

\begin{tabular}{|l|c|c|}
\hline \multicolumn{1}{|c|}{$\begin{array}{c}\text { Value of Assets } \\
\text { Dfl million }\end{array}$} & Corporate pension funds & Sector pension funds \\
\hline$<100$ & 2 & 2 \\
\hline $100-499$ & 11 & 17 \\
\hline $500-999$ & 6 & 10 \\
\hline $1,000-4999$ & 21 & 12 \\
\hline $5,000-9,999$ & 10 & 5 \\
\hline $10,000-19,000$ & - & 2 \\
\hline $20,000-49,000$ & 5 & 1 \\
\hline $50,000-99,999$ & - & 1 \\
\hline$>100,000$ & 1 & - \\
\hline & 56 & 50 \\
\hline
\end{tabular}

Source: Vereniging van Bedrijfspensioenfondesen, Rijswijk, The Netherlands

1\%. Cited as case C-219/97 Maatschappij Drijvende Bokken BV v. Stichting Pensioenfonds voor de Vervoer-en Havenbedrijven and incorporating Albany International BV v. Stichting Bedrijfspensioenfonds Textielindustrie and Brentjens' Handelsonderneming BV v. Stichting Pensioenfonds voor de Handel in Bouwmaterialen (decision rendered 21 September 1999). 
The Advocate General Francis Jacobs opinion which focused upon Albany (C-67/96) was delivered 28 January 1999.

2 . In this paper, we emphasise EU regulation rather than national regulation of the financial services industry. This is an important short-coming, made necessary by limits on the scope of our paper. We note, however, that there may be significant national jurisdictional issues involved in the cross-over of funds-firms between different kinds of financial products. Whereas the Dutch insurance regulator is rightly concerned with the financial integrity of funds (assets to liabilities), there may be significant "gaps" in the regulatory regime with respect to funds' other financial products. This is an important issue in throughout Europe, the UK and in the US. See, for instance, the May $5^{\text {th }} 1999$ testimony of Arthur Levitt, the SEC Chairman before the US Congress House Committee on Commerce regarding the Financial Services Act of 1999 (and repeal of the Glass-Steagall Act) [www.sec.gov/news/testimony/tsty/099.htm]

3\% In Arrow's (1984, pp. 147-149) treatment of adverse selection and moral hazard, he directly associated these concepts with market failure and the problems of asymmetrical information and unaccounted behavioural responses. Drawing upon experience in the insurance industry, he noted that individuals know more precisely than insurance companies their proper risk-rating. Hence, high-risk individuals tend to buy more insurance than lowrisk individuals because for the former group the offered insurance is a bargain compared to the value of offered insurance to the latter group (adverse selection). With respect to moral hazard, he noted that having insurance cover may encourage individuals to be less careful than they may otherwise be; in effect, some one else covers the full costs of their actions. In this paper, we emphasize selection bias rather than adverse selection, referring to the selective nature of insurance offers made to individuals by insurance companies.

4. Having interviewed many global, EU and national financial service firms across Europe, it is apparent that the biggest players are forceful advocates for a market "solution" to the European demographic bomb. In particular, many suggest some version of individual retirement accounts managed and invested by the investment community. This is said to be the best way of shifting the burden of retirement of the state and the EU while building an equity culture in Europe. By contrast, we tend to agree with Orszag and Stiglitz (1999) in that each country brings to the twenty-first century their own solution to retirement income planning, with their own particular advantages and disadvantages. Of course, this does not 
mean that each country's solution will remain locked-up by history and geography. Quite the contrary. This paper deliberately situates the Dutch model in the wider European context.

5 /. It is worth noting, however, that the concept of social solidarity is currently in vogue in Anglo-American management consulting. For example, Goffee and Jones $(1998,28)$ develop their well-known Harvard Business Review paper on corporate culture, arguing in favour of "[s]olidaritic relationships [that] are based on common tasks, mutual interests, and clearly understood shared goals that benefit all parties... . Labor unions are an archetypal example of high-solidarity communities." By their assessment, the coherence of shared goals drives the organization even if the external environment is hostile and economically unforgiving.

$\%$ We have resisted the temptation to explicitly link these cost advantages to the theory of market competition. More detail on the types of costs referred to in our argument can be found in Vickers (1997) and Viscusi et al. (1995, chs. 6 and 11). See especially their discussion of switching costs.

7 . Private insurance companies would inevitably select amongst eligible plan participants reducing the costs for some (firms and younger workers with clear health records) but increasing the costs for others (firms and older workers with health complications) to the point where coverage rates must decline. There is a risk that the insurance industry would not offer coverage to those types of workers most in need of coverage (selection bias) thereby thwarting the goals of government policy. Mandatory coverage would then become the only alternative (witness the Australian and Swiss examples; see Edey and Simon 1998).

$8 /$ Even if data were readily available on these issues, there would be the inevitable problems of comparing performance using different, perhaps non-commensurate, benchmarks. See Clark (2000, ch. 5) for related problems in the Anglo-American pension fund investment management industry.

9 . It must be emphasized that drawing precise implications from pension funds' investment performance is a very difficult. In Clark (2000, chs. 4 and 5), there is a detailed treatment of this issue, noting the significance of unaccounted (random) year-to-year volatility of performance against accepted bench marks. In many respects, trends over longer time frames (up to 5 years) are more acceptable empirical measures of performance. 
$10 \%$ The principal-agent problem looms large in the modern firm, something widely acknowledged in the academic and policy-related literature (see Pratt and Zeckhauser 1986 for a useful over-view).

$11 \%$ An original treatment of the difficulties of collective action in large groups is to be found in Olson (1965). More recently, Bennett (2000) demonstrates how the collective interest becomes increasingly governed by central managers rather than diffuse owners as mutual insurance institutions expand.

$12 \%$ Throughout the paper, we refer to Articles 85,86 and 90 in accordance with the Treaty of Rome and the deliberations of the ECJ. Of course, this numbering system has changed very recently in accordance with the Treaty of Amsterdam (now Articles 81, 82 and 86). Evans (1998) provides a useful historical commentary on the various treaties, and the consequences of the Treaty of Amsterdam for the system of numeration.

13\% Notice in the AG Jacobs opinion, doubts were raised about the status of collective bargaining agreements in relation to EU competition policy. The AG provides an extensive analysis of the facts of the case, and the issues raised in EU law. He also reviewed the current exemptions and modes of treating collective bargaining in the western world, arguing that the legal status of the various international social charters on workers' rights to organisation were problematic, to say the least. Nevertheless, he managed to find reasons to conclude that the Dutch sector plans were outside of the scope of Article 85 and that the sector funds were, in fact, properly treated as economic undertakings. Nevertheless, he suggested that if the ECJ were to allow the sector funds privileges, it would be an exceptional decision in the light of previous related decisions.

14 . The Court referred to a set of cases involving countries' social security schemes, including Hofner and Elser [1991] ECR I-1979, Poucet and Pistre [1993] ECR I-637 and Federation Francaise des Societes d' Assurance and Others v. Ministere de l' Agriculture et de la Peche [1995] ECR I-4013. The Court noted re Hofner its functional definition of undertakings, the distinction to be drawn between social security systems based upon contributions as opposed to social solidarity (Poucet and Pistre), and the irrelevance of an organisation's profit-making status for determining whether such an organisation was "carrying on an economic activity" (p. 12) (referring to the Federation decision). 
15\% A recent evaluation of ECJ decision making and the regulatory actions of DGIV questions the coherence and significance of EU competition policy (see Neven et al. 1998). We are perhaps more sympathetic to the need for a balanced approach to EU policy making, in general, than Neven et al. and we find merit in the ECJ decision excluding Dutch sector pensions from the scope of Article 85. Social policy has, and deserves, its own arena even if this affects European economic integration.

16/. Faull and Nikpay (1999, ch. 9) provide an authoritative review of the European Commission's treatment of the geographical dimensions of financial markets. In the main, they stand by the conventional national definitions of such markets, referring to issues such as the scope of existing distribution channels (see 9.139-9.141). But they also acknowledge that some kinds of financial institutions and some kinds of financial firms may need to be spread risks across larger geographical units, like Europe. To economic geographers, the Commission's assumed geography of financial markets appears remarkably hard to justify.

17 . The issue of national spheres of influence and responsibility with respect to EU mandates and decision-making is far more complicated than this brief commentary allows. See de Burca (2000) on the principle of subsidiarity, arguing that it is a guide for institutions' powers rather than a judicial right conferring powers or limiting powers within a multi-tier system of governance. Scott (2000) is similarly instructive on the contested issue of national powers, noting the evolution of pan-European legal norms and customs regarding the separation of powers between tiers of government.

18\% See Helm and Jenkinson (1997) on the problematic issues involved in moving from a regulated, captive market to a competitive market situation. 